\title{
The use of betel (Piper betle) leaves for maintaining the health of women and children at various ethnic groups in Indonesia
}

\author{
LUCIE WIDOWATI ${ }^{1, \vartheta}$, LESTARI HANDAYANI ${ }^{2}$, ROHMAT MUJAHID ${ }^{3, \bullet \bullet}$ \\ ${ }^{1}$ Center for Research and Development of Health Resources and Services. Jl. Percetakan Negara 29, Jakarta Pusat 10560, Jakarta, Indonesia \\ Tel. +62-21-4259860, `email: luciewidowati@yahoo.com \\ ${ }^{2}$ Center for Humanities and Health Management. Jl. Percetakan Negara 29, Jakarta Pusat 10560, Jakarta, Indonesia. Tel. +62-21-42872392, 4241921, \\ vemail: lestarimail@yahoo.com.sg \\ ${ }^{3}$ Research and Development Center for Medicinal Plants and Traditional Medicines. Jl. Raya Lawu No 11, Tawangmangu, Karanganyar 57792, Central

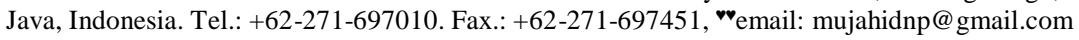

Manuscript received: 2 June 2020. Revision accepted: 14 September 2020.

\begin{abstract}
Widowati L, Handayani L, Mujahid R. 2020. The use of betel (Piper betle) leaves for maintaining the health of women and children at various ethnic groups in Indonesia. Nusantara Bioscience 12: 120-126. Betel is considered as one of the popular medicinal plants. Traditional uses of betel are mainly for maternal and child health, and frequently applied by the local communities. The study was carried out to determine the traditional use of betel. The method used a descriptive approach by analyzing the data collected from the RISTOJA Project in the year of 2012, 2015, and 2017. Data collection was conducted in 34 provinces of Indonesia through the survey of local knowledge of ethnomedicine and community-based medicinal plants. We collected the data using semi-structured interviews with traditional healers. The study revealed some medicinal related purposes, such as (i) Beauty care/cosmetic; (ii) Female genital organ; (iii) Fertility disorders; (iv) Pre and postnatal; (v) Stimulating breast milk, and (vi) Baby and children care. The RISTOJA project proved that the use of betel in health care for women and children is a lot so that it should be more developed. Previous studies also proved that betel is efficacious and safe for women and children. On the contrary, unhygienic way of services in traditional rituals and beliefs need to be supervised so that there is no harmful effect on the consumer. We propose establishing guidance to the traditional healers so that they can understand the safety and efficacy of traditional medicine and hygienic traditional health services.
\end{abstract}

Keywords: Community health, health service, Piper betel, traditional healer

\section{INTRODUCTION}

Women go through their life cycle in several stages, namely conception, babies, adolescents, adults, and old age. Women get through it with various health problems. They have to make preventive and promotive efforts for their health. Some of them use medicinal plants and traditional medicines, even though chemical drugs are easily found from drug-stores (NIHRD 2013). According to the data of NIHRD (2018), $31.4 \%$ out of the $98.5 \%$ of the total population use traditional health services from the traditional healers, and $48 \%$ are self-medicating using medicinal plants from their garden. Medicinal plants have been traditionally used for various health needs by women at various ethnic groups in Indonesia. One of the popular medicinal plants used for self-medication is betel leaf. Betel grows by spreading and leaning against tree trunks, 5-15 meters long. Betel belongs to the family Piperaceae. It is easily found and expands well in various levels of altitude. Betel is planted in pots or gardens for the need for family self-medication. Betel is good growing under the shade of tree. Betel has many local names, such as ranub (Aceh), sereh (Gayo), seureuh (Sunda), suruh (Java), sere (Madura), base (Bali), dontile (Gorontalo), gies (Halmahera) (NIHRD 2000).

Betel has also been used in many countries, such as Bangladesh, China, India, Malaysia, Nepal, and Pakistan
(Chauhan et al. 2016). Traditional uses of betel for women and children's health care include weight loss, treating coughs, stimulating breast milk, anti-inflammatory, mastitis, foul body odor, preventing and treating vaginal problems, reducing vaginal itching, and treating wounds (Dwivedi and Triphati 2014). Betel is known by Indonesian people to maintain maternal and children's health. The use of betel leaf as self-medication among Madurese women is for various reproductive health purposes. Indonesian people name it "Jamu" for traditional Medicine (Lestari and Suharmiati 2009). Betel is also used as one of ingredients for teenage girls' traditional medicine, for example, "Jamu Pengantin" for caring bridge health, "Jamu Sari Rapat" for the health of women's reproductive organs, "Jamu Keputihan" to treat Leucorrhoea/Fluor albus, "Jamu Bersalin" to caring postpartum mothers, and "Jamu Subur Kandungan" for female fertility to easily get pregnant (Mudjijono 2014). Madurese women use the herb manjakani (Quercus infectoria) and betel to avoid abnormal vaginal discharge and menstrual disorders (Putri et al. 2018).

\section{MATERIALS AND METHODS}

The study used a descriptive approach using the data of the RISTOJA Projects on medicinal plants in the year of 
2012, 2015, and 2017. RISTOJA was the national program under the Research and Development Center for Medicinal Plants and Traditional Medicines National Institute of Health Research and Development (NIHRD), Indonesia Ministry of Health. The program was cross-sectional research by interviewing traditional healers at various ethnic groups in Indonesia that illustrates the use of medicinal plants. In each ethnic group, five traditional healers were interviewed to gain knowledge and how to use the medicinal plants. We collected 2,600 medicinal plants, including betel, categorized in 74 groups of diseases/ailments. This study focused on wet and dry betel for women and baby health care. RISTOJA data were deposited in the Data Management Laboratory, NIHRD.

The data were collected from the overall RISTOJA's data by officers in data management. The collected data included ethnic group, study area, traditional healer, and the use of betel especially for women and baby health care. This study followed the ethic in ethnobotanical study (ISE, 2006).

Number of formula recorded in 2012, 2015 and 2017 were 15,$773 ; 10,047$ and 6,193 respectively. Overall, we recorded 32,013 formulas used in 74 groups of diseases/ailments. The use of herbal concoction, including Piper betel, by traditional healer, spread across 274 ethnic groups or observation points. The surveyed ethnicity is presented in Figure 1. The map showed that betel was found and used in almost all provinces of Indonesia.

\section{RESULTS AND DISCUSSION}

\section{Women and children health disorders}

There were 131 of 872 formulas $(15 \%)$ used by the traditional healer to treat maternal and children health disorders. Mother and children care using betel were grouped into (i) Beauty care/cosmetic; (ii) Female genital organ; (iii) Fertility disorders; (iv) Pre and postnatal; (v) Stimulating breast milk and (vi) Baby care. The use of betel for women by ethnic groups in Indonesia from its hereditary is separated. The largest number of ingredients used was for pre and post-partum, i.e. 45 formulas (Table 2).

Table 2. The number of formula in each use

\begin{tabular}{lc} 
Uses & Number of formulas \\
\hline Cosmetic/beauty & 19 \\
Female organ disorder & 41 \\
Fertility disorder & 14 \\
Pre and postnatal & 45 \\
Breast milk & 1 \\
Baby/ child & 11 \\
& 131 \\
\hline
\end{tabular}

(NIHRD 2012; NIHRD 2015; NIHRD 2017)

Table 1. The number of ethnic, traditional healer, and the formula

\begin{tabular}{lccccc}
\hline Year & \multicolumn{5}{c}{ Number of } \\
\cline { 2 - 6 } & Ethnic & Point of observation & Trad healer & Formula & Formula with betel \\
\hline 2012 & 209 & 255 & 1,324 & 15,773 & 324 \\
2015 & 96 & 100 & 525 & 10,047 & 371 \\
2017 & 100 & 100 & 505 & 6,193 & 177 \\
Total & 405 & 455 & 2,354 & 32,013 & 872 \\
\hline
\end{tabular}

(NIHRD, 2012; NIHRD, 2015; NIHRD, 2017)

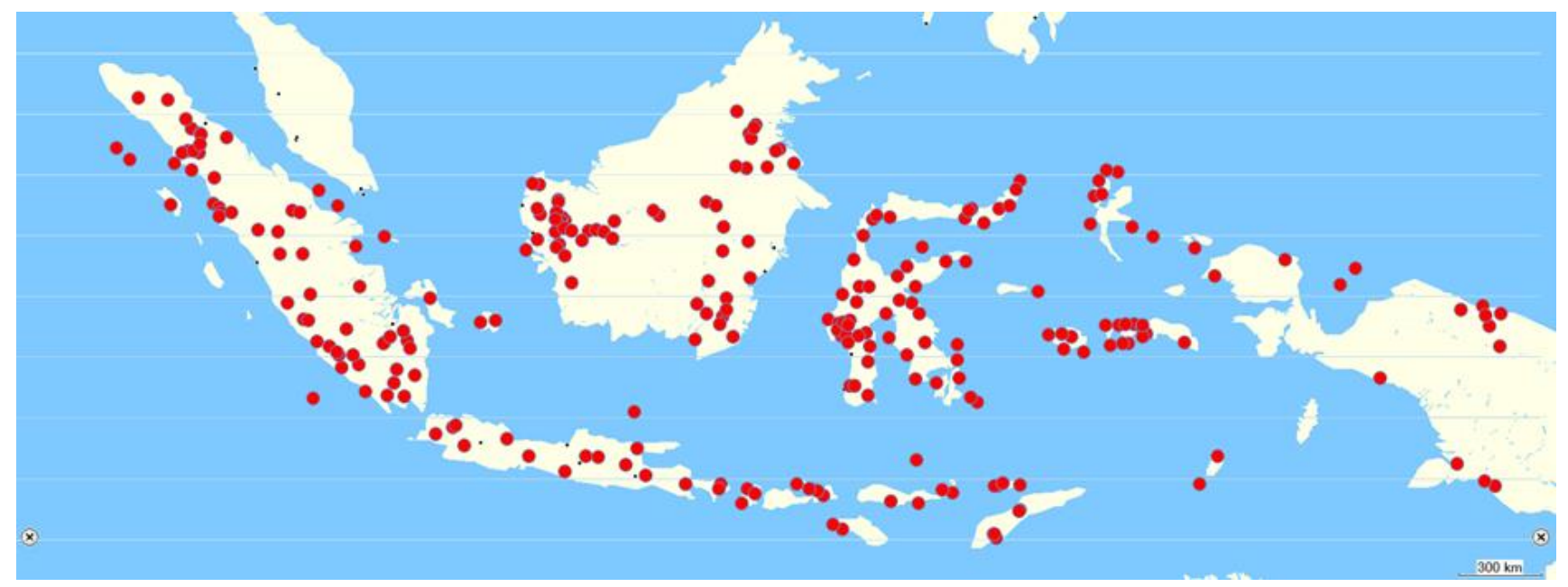

Figure 1. Map showing ethnic groups used Piper betel in health care (taken from GARMIN mapping) 
Tabel 3. Traditional uses of betel leaves for maternal and children health care

\begin{tabular}{ll} 
Beauty care \\
\hline Ten leaves and ten stems of betel mixed with five cups of water were then cooked and used for bathing once every day for a \\
week.
\end{tabular}

2. Seven betel leaves, three aloe leaves (Aloe vera), and 7-9 kapuk leaves (Ceiba pentandra) were crushed. The juice is smeared on the head and covered with bandages for seven days, do not open until get well.

3. Betel leaves, kunyit rhizome (Curcuma longa), and manjakani (Quercus infectoria) were pounded, then made into a strand and dried, mixed with water to make a paste, applied to the face.

4. Five-seven betel leaves were washed with clean water. Added one cup water and boil till remain $1 / 2$ glass of liquid. Drink 2 x $1 / 2$ cup per day for 1 or 2 days.

\section{Female organ disorders}

1. Betel leaves were washed with clean water, added two cups of water and boil till remain one cup of liquid, let it cool, then drink.

2. Betel leaves were boiled together with clean water, let it cool, and use to wash female genital organs.

3. Some red betel leaves were mixed with clean water and boiled. Drink boiled water regularly.

\section{Fertility disorders}

1. Three betel leaves were eaten by a married woman. The leaves are eaten, before husband and wife have sexual intercourse, for seven nights.

2. Betel leaves, roots of Phyllanthus niruri, and pinang fruits were chewed and swallowed by water (essence starch). Husband and wife separated the waste and ate together.

3. Three betel leaves and one young pinang fruit were peeled with a knife. One onion and one ginger rhizome (Zingiber officinale) were crushed until smooth. Applied to the stomach, and the rest is eaten.

4. Betel leaves and star fruit (Averrhoa carambola) were boiled with three glasses of water till became one glass. Drink half glass, and another half glass to wash to the female organs.

5. Seven-12 betel leaves, 12 sheets of kayu jawa (Lannea alata), and about5 $\mathrm{cm}$ of pinang root (Areca catechu) were cut into small pieces. All ingredients were boiled with enough water, let it cool, and drink two times a day.

6. Seven pieces of betel roots, seven pieces of pule bark (Alstonia scholaris), and seven pieces of kunyit putih rhizomes (Curcuma zedoaria) were boiled with 21 cups of water. Drink as needed (or if thirsty).

Abstinence: (i) Do not lift heavy loads; (ii) It is prohibited to consume excessive sugar; (iii) Do not eat papaya leaf vegetable mixtured herbs were drunk by the wife. For pregnant women, it is not allowed.

\section{Pre and postnatal care}

1. Betel root, pinang root (Areca catechu), Sembung root (Blumea balsamifera), coconut root (Cocos nucifera), kumis kucing leaves (Orthosiphon aristatus), jahe wangi rhizome (Kaempferia galanga) and temulawak rhizome (Curcuma xanthorrhiza) were washed, chopped, boiled with three buckets of water.

2. Ten cm of majau stems (Quercus infectoria), tero root (Stachytarpheta jamaicensis), dried betel fruit, pinang fruit (Areca catech $u$ ) were boiled with one-liter water till remain $1 / 2$ liter, and drink $1 / 2$ cup.

3. Rice washed with boiled water, used the first washing water, added kencur rhizome (Kaempferia galanga), and betel leaves $(P$. betel) that have been mashed, and drink.

4. Betel leaves (P. betel), kunyit leaves (Curcuma longa), and pedas rhizome (Zingiber officinale) were boiled and drink for 40 days after the mother delivered labor.

5. Betel leaves (P.betel) were squeezed with salt, added $1 / 2$ cup water, then drink.

6. Kunyit bolai (Zingiber zerumbet) and betel leaves $(P$. betel) were cleaned and pounded, then filtered and drink.

7. Betel leaves, one pinch of gambir (Uncaria gambir), $1 / 2 \mathrm{~cm}$ of jeringau rhizomes (Acorus calamus), $1 / 2 \mathrm{~cm}$ of singkelu rhizome (Kaempferia galanga), $1 / 2 \mathrm{~cm}$ of kuni bonglai rhizome (Zingiber montanum), and one pinch of lime betel were mixed and consumed for nine days after mother delivered labor.

\section{Stimulating breast milk}

1. Betel leaves were chewed with one handful of papaya roots and pinang fruit (Areca catechu), applied to the breast, and massage from back to front.

\section{Babycare}

1. Betel leaves were rubbed into the baby's chest, place the betel leaves under the pillow or baby's head.

2. Betel leaves, kunyit rhizome (Curcuma longa), and salt were crushed and added with pure coconut milk and then heated and applied to the sick of the body.

3. Betel leaves, pinang fruit (Areca catechu), merica (Piper niger), gambir (Uncaria gambir), keciyor (Kaempferia galanga), and betel lime were chewed and applied to the baby's belly (umbilical cord).

\section{Child care}

1. Two betel leaves (P. betel) were squeezed, and corked/stuffed on a bleeding nose until the blood stop.

2. Betel leaves were applied to the source of inflammation

3. Young pinang fruit (Areca catechu) and two-finger joints $(4 \mathrm{~cm})$ of kunyit rhizome (Curcuma longa) were burned, took betel leaves, put all ingredients into one cup of boiled water and drink to stimulate the appetite. 


\section{Formula and how to provide}

Betel can be a single or mixture of ingredients, and it can be oral concoctions or external concoctions with a simple method. Decoction is a standard method used to get in drink. Also, there were drinking potions for children that are made by soaking. External formulas were generally only finely ground and applied to the body part treated. Some were used by rubbing on specific aspects of children's bodies. Table 3 shows the use of betel in the form of a single ingredient or mixture and applied method.

\section{Discussion}

Piper betle helps in curing various diseases like diabetes, hypertension, brain toxin, halitosis, boils and abscesses, obesity, wound healing, voice problems, conjunctivitis, constipation, headache, hysteria, itches, mastitis, mastoiditis, swelling of gum, rheumatism, abrasion, cuts, and injuries (Chauhan 2016). Betel leaf contains essential oils consisting of bethephenol, chavicol, chavibetol, estrogen, eugenol, and carvarool (Sengupta and Banik 2013). Eugenol, one of the principal constituent of betel leaf has also been shown to possess antiinflammatory effects in various animal models of studies with various inflamogen (Musdja et al. 2019), and was identified as the antifungal principle in the oil (Pradhan 2013). Phenol compounds as antioxidants can help or maintain healthy cells. The phenols content in betel leaves' antiseptic properties is five times more effective than ordinary phenols chavicol as an antiseptic (Ningtias et al. 2014).

There were 131 of the 872 formulas containing betel used by the traditional healer. Potions were used by the traditional healer to treat 74 types of disease complaints. The mothers have a heavy period after giving labor. She must take care of her baby, besides taking care of herself. The culture of hereditary use is essential in Indonesia, including by traditional healers. RISTOJA's activity was to explore traditional health care knowledge about the diseases and the formula used. The number of formulas and information from traditional healers needs to be scientifically explained. Although the use of betel is not always a singular form, scientific reports for betel can be useful in explaining the efficacy and safety.

There were 19 beauty formulas, one of which was to get rid of acne by applying or drinking. This study supported previous research on the anti-bacterial properties of Propionibacterium acnes. Research on antibacterial properties of Propionibacterium acnes supports betel in adolescent girls, which is also informed by traditional healers as a part of beauty care. The antibacterial activity test of $P$. acne using the disc diffusion method on an ethanol extract of betel from the highlands was able to inhibit the growth of bacteria higher than betel from the lowlands (Widyaningtias et al. 2014). Several studies have supported the use of betel as an alternative therapy for acne vulgaris (Carolia and Noventi 2016).

Treatment of female organs with betel is applied by washing the female organs or by drinking. There were 41 formulas with betel for the treatment of female organs. Generally, female organ disorders are due to fungal infection (Aspergillus flava). Women's complaints due to candidiasis are quite disturbing. Betel leaf can be useful for pregnant women, i.e. pregnant women usually experience vaginal odor and vaginal itching. Betel leaf boiled water is used to rinse the vagina. The presence of fungi and bacteria cause disorders of the female organs. Based on a preliminary survey using an interview conducted on February 16, 2015, at a high school, SMA Negeri 1 Sukodadi East Java. It was from ten teenagers who experienced $60 \%$ vaginal discharge. The data assumed that the incidence of vaginal discharge in adolescents is still high (Sulistyowati and Amalia 2016). Several related studies support the use of betel for this disorder. Sobel from Wayne State University wrote that $75 \%$ of women in the world experience vaginal discharge at least once in their life cycle, and $45 \%$ of women experience vaginal discharge twice or more during their life cycle (Marhaeni 2016). Nazmul research in Malaysia showed that betel contains anti-fungal, especially for A. flava (Nazmul 2013). Several anti-fungal tests on betel leave extract were carried out, and they showed that betel has antifungal properties both against $A$. flava and T. rubrum (Patra et al. 2016).

The efficacy of betel leaf in curing vaginal discharge was obtained by clinically tried. Betel leaf has more significant properties compared to the placebo. Testing involved 40 patients with leucorrhoea who were not pregnant, suffering from diabetes mellitus, liver, and kidney disease. Twenty of them got betel leaves, while the rest was given a placebo. Both betel leaves and placebo were given to the vagina before the patient sleep (at night) for seven days. Out of 40 patients, 22 received reexaminations, i.e. 11 placeboes, and 11 betel leaf. The results prove that about 90.9 percent of patients who received betel leaves were declared cured, whereas, in the group given a placebo, it was only 54.5 percent (Sulistyowati and Amalia 2016). Eugenol in betel leaf is useful to kill the fungus Candida albicans. Betel contains tannin, which is helpful as an astringent (reducing the secretions in the vagina), so that betel can treat vaginal discharge (Ningtias et al. 2014; Sulistyowati and Amalia 2016).

Observation on women in Gampong Dayah Bubue, betel leaves used in daily life for natural feminine hygiene. Betel leaf is prepared in the form of boiled water. The majority who still use green betel leaf decoction were adolescents aged 19-22 years and young mothers aged 2225 . These two groups are still actively using green betel leaves. Groups of teenagers at the age of 16-25 years, only a few used betel extract packaged in bottles that are sold at the nearest shops. The second highest percentage was unmarried women at the age of 26-35 years, due to the same reason, lack of personal hygiene, and hormone factors. The low percentage found on mothers aged 46-55 years. That is due to most elderly mothers in the Bubue Dayah Village, from younger age who have a habit of chewing betel until old age. This behavior is essential to prevent them from being infected candidiasis (Zuraidah 2015). 
Contraception originating from nature is still used and becoming a trend in densely populated countries. In comparison, the use of conventional contraception for some women causes side effects and other obstacles. Betel has properties as natural contraception proven by research. The thyroid gland and hormones play an essential role in the development and function of the reproductive system. Some reports state that thyroxine levels are inversely correlating with prolactin levels. Likewise, estrogen levels are positively connecting with prolactin levels. Potential contraceptive effects from betel leaves, performed on nine female albino rats were divided into three groups. The control group was given standard food; group $10.5 \mathrm{ml}$ betel extract; group $21 \mathrm{ml}$ betel extract, for two weeks. The findings supported other studies that show a correlation between thyroxine, prolactin, and estrogen. It also indicated that Piper betel is an effective and safe natural contraception (Mariano et al. 2017).

Betel leaf extract reduced testosterone levels, sperm count, spermatozoa motility, and acidity of albino rat seminal plasma. Because of that, betel harms the reproductive system of male rats. This harm is especially actual of arachne, an alkaloid, which is considered to have the same effect as cocaine (Rekha et al. 2014). Ethanol extract $100 \mathrm{mg} / \mathrm{kg}$ body weight was given to female albino rats, has an anti-estrogenic effect. Giving the ethanol extract causes a decrease in reproductive organs, reduces circulation, and reduces the enzyme phosphatase acid, SGOT, and SGPT (Pradhan et al. 2013). The water and ethanol extracts have anti-fertility properties through their antiestrogenic properties. Piper betel can be as anticontraception (Biswal 2014).

The pre and post-partum potions with betel were the largest ingredients, within 45 formulas. Mothers in pregnancy, sometimes experiencing health problems that need treatment. Conventional medicine is considered to have side effects, or undesirable effects, on their baby. Instead of modern medicine, traditional medicine made from betel leaves can be a safer alternative. Thrush and cough in pregnant women can be treated by drinking betel leaf decoction or mouth rinse. Betel leaf stew can also treat bad breath of pregnant women by gargling regularly. Treating diarrhea in pregnant women can also use betel. Diarrhea due to wrong eating can be treated by drinking betel leaves boiled water until diarrhea stops. The impact of childbirth pregnancy requires that of the lower abdominal muscles withstand the fetus uterus burden. Pregnant women during childbirth must push to remove the baby. This situation causes some mothers to experience interference in the form of hemorrhoids. Betel leaf is also beneficial for healing hemorrhoids by mixing 11 betel leaves with $1 / 4$ turmeric segments and $100 \mathrm{gr}$ of the tamarind fruit. The mixture was boiled, and taken to taste (Lestari and Suharmiati 2009; Widyasari et al. 2012).

Regular services by traditional healers at home are still relatively high. The risk of childbirth is the presence of birth canal injury (perineum), which handled unhygienic, can cause birth canal infections. Research on betel extract in experimental animal wounds showed that betel leaf ointment can accelerate artificial wound healing in experimental animals by suppressing inflammation and forming the new epithelium in wounds (Puspa and Fatonah 2019). One of the formulas for postpartum was turmeric leaves, mixed with spices and betel boiled with water. Potions taken 40 days after giving labor are intended to accelerate postpartum wound healing. Betel leaf contains tannins, saponins, alkaloids, flavonoids, steroids, terpenoids, and phenolic components. Phenol compounds in the form of essential oils are consisting of bethephenol, chavicol, sesquiterpenes, hydroxychavicol, chavibetol, estrogen, eugenol, and carvarool which may kill germs and fungi, and also antioxidants that accelerate the wound healing process (Sucipto et al. 2016).

The results of other studies proved the benefits of betel for healing postpartum wounds. A preliminary survey by interviewing midwives in Sumbermulyo Village, Jogoroto District, East Java, in February 2010 showed that seven of nine postpartum mothers used betel leaves (77.78\%), and the rest did not use betel leaves $(22.22 \%)$. Four of the nine mothers were under episiotomy $(45 \%)$, and the rest experienced spontaneous tears $(55 \%)$. The observation showed six mothers $(67 \%)$ recovered in seven days, and the rest were for more than seven days (Kurniawati et al. 2015). The author also surveyed in Ngrimbi Village and Banjaragung Village, Jombang District, East Java, and the results revealed that $90 \%$ of puerperal mothers used betel leaves as a medicine to treat itching in the female area and accelerate the healing of perineal wounds (Kurniawati et al. 2015). Research on betel extract in experimental animal's injuries showed that betel leaf ointment can accelerate wound healing in experimental animals by suppressing inflammation and forming the new epithelium in wounds (Puspa and Fatonah 2019).

Another disorder that mothers often experience after childbirth is the birth canal area's pain after delivery. The Madurese uses formula that contains betel leaves. When the mothers started to experience the symptoms, they were given a mixture of clove, garlic, and some Acorus calamus leaves (Widyasari et al. 2012). The results on the nature of betel analgesics which were performed on experimental animals using the hot plate method showed that a dose of $100 \mathrm{mg} / \mathrm{kg}$ body weight can reduce pain due to heat (Venkateswarlu and Devanna 2014).

The research conducted on the ability of betel leaf and stem extracts to heal wounds showed that female albino rats injured on the back and received $10 \%$ betel ointment on the open wound surface, betel ointment showed a significant effect with a comparison of the ointment povidone-iodine group and the control group (Rekha et al. 2014; Pradhan et al. 2013; Nilugal et al. 2014). Efficacy of healing wounds from betel leaves which was shown in the previous studies showed that betel leaf with methanol extract can increase fibroblast cell proliferation and improve wound healing ability in vitro and in vivo in experimental animals (Lien et al. 2015).

Physical recovery, especially the part of the womb, was implemented by using traditional ingredients, which determined from the results of RISTOJA. The Gayo ethnic group (Aceh) used betel leaves in the form of chewing, then mixed with kitchen ash, and put into the vaginal canal 
for one week to speed up vaginal drying (Fitrianti and Angkasawati 2015).

After delivering labor, a mother will experience physical changes, especially in the uterus, including the fetus, and breasts that contain milk for the baby's need. Breastfeeding mothers expect smooth breast milk so that they can meet the nutritional needed of the baby. In other words, mothers are hoping and to have smooth breast milk to meet the dietary needs of the baby. It is a typically traditional way to use betel to stimulate breast milk. Betel can accelerate the release of breast milk by attaching the leaves with cooking oil or mustard oil (Chauhan et al. 2016; Sengupta et al. 2013). Betel can also be used to treat mastitis in nursing mothers. Mastitis is an inflammation of the udder tissue caused by microorganisms, generally bacteria, chemicals, and mechanical injury. Betel leaf decoction (Piper betel L.) has the same effectiveness as the commercial antibiotic penicillin-dihydrostreptomycin in inhibiting gram-positive bacteria growth. (Lutviandhitarani et al. 2015).

Based on the data of RISTOJA, the uses of ingredients for women's postpartum were tightening the muscles, heal postnatal suture wounds, restore uterine size, smoothen breast milk, restore loss of stamina, and speed up postpartum blood release. The number of formulas and benefits informed by traditional healers are needed to explain scientifically. Although the use is not always in a single form, scientific reports support that betel can be useful in the efficacy and safety.

The use of betel for babies was only for illness, and so far there is no information for the pain. Generally, the formulas are mixed with other medicinal plants, used to be rubbed or attached to the sick body. Meanwhile, treatment in children is for swelling, nose bleeding, and stimulating the appetite.

Treatment for children is not for trial and error. For example, the Madurese used betel leaves for thin babies due to malnutrition. The ingredients were betel leaves, and "empon-empon" such as curcuma, galangal, ginger, turmeric, temu ireng, lempuyang emprit, bitter, brotowali, kapulaga, fennel, and papaya leaves. All materials were mixed and grounded using stone with a little water and wrapped in a cloth, then fed to the baby (Widyasari et al. 2012). Betel in the ingredient may have antibacterial properties and is potential as an antibacterial. The study from crude extracts of betel leaves from several solvents showed activity against most of the tested bacteria, i.e. E. coli, $P$. aeruginosa, and $S$. aureus (Shah et al. 2016). Ethanol extract of betel leaf can inhibit broad-spectrum of bacteria $(P$. aeruginosa, $P$. vulgaris, $S$. aureus, $K$. pneumoniae), compared with antibiotics ceftriaxone (Datta et al. 2011). Hydroxychavicol isolated from green betel chloroform extract can inhibit $S$. aureus and $S$. pyogenes (Shah et al. 2016). Power as an antibiotic proved in water extracts of fresh betel leaves can hinder the growth of Bacillus and $P$. aeruginosa compared to penicillin standards (Shukla et al. 2009).

\section{Safety of use}

The empirical use showed that betel is safe to use. Meanwhile, the safety data of the acute toxicity of betel leaf water extract was safe to use up to $1,000 \mathrm{mg} / \mathrm{kg}$ body weight. Betel stalk was nontoxic as proved by hematological, biochemical profiles, and enzymatic studies (Sengupta and Banik 2013).

A sub-chronic toxicity test (14 days) and chronic toxicity (45 days) on ethanol extract and water extract at a dose of $1500 \mathrm{mg} / \mathrm{kg} \mathrm{BW}$ was safe to use and did not affect the blood image, blood biochemistry, and enzymes (Arambewela 2011). The concern for using betel is when chewing with areca nut and gambir consumed by pregnant mothers. The use of betel as a material of "chewing" is commonly found as a public habit, including pregnant women. The effect of chewing activity is to increase salivation, perception of feeling of invulnerability, stimulation of muscular motion, and euphoria (Sucipto et al. 2016). Study conducting on 400 pregnant women with a habit of betel chewing in Papua New Guinea, compared to a group of pregnant women who have no habit of betel chewing. The study reported that pregnant women, who during pregnancy chewed betel, significantly increased adverse outcomes for babies in Taiwan, Malaysia, and Papua New Guinea. The effect is similar to that of mothers who consume alcohol or tobacco during pregnancy. Lower birth weight reduced birth length and significantly higher early delivery (Hossain et al. 2017).

Based on the data of RISTOJA, the use of betel for women and children was mostly for pre and post-partum care and has been supporting by several scientific studies. Thus, it is essential to preserve empirical ingredients for maternal and children's health, especially the people living in remote areas or areas difficult to reach healthcare facilities.

In conclusion, the traditional use of betel leaves as health care and treatment for women is still widely practiced by various ethnic groups in 34 provinces of Indonesia. The use as a children's health care is still minimal. The use of betel practiced by traditional healers is generally part of the ingredients. The use of betel in women and children's health care can be seen from the various benefits. Scientific studies ranging from ethnomedicine, community research, pre-clinical, and clinical prove the efficacy and safety of betel in the treatment and health care of women and children. Traditional services related to rituals and beliefs need to get attention so that people do not experience harmful effects due to unhygienic practices. We propose establishing guidance to the traditional healers to understand safety and efficacy, and provide hygienic traditional health services. It is important to provide learning to the traditional healers about the effects of using betel orally for pregnant women.

\section{ACKNOWLEDGEMENTS}

The authors thank the Data Management Laboratory of the National Institute of Health Research and Development (NIHRD), which approved our proposal for further analysis of the RISTOJA data in the year of 2012, 2015, and 2017. 
The authors also thank all the team in the RISTOJA Project. All authors contributed equally to this work and discussed the manuscript at all stages.

\section{REFERENCES}

Arambewela LSR, Arawwawala LDAM, Kumaratunga KG, Dissanayake DS, Ratnasooriya WDKS. 2011. Investigations on Piper betle grown in Sri Lanka. Pharmacogn Rev 5 (10): 159-163.

Biswal S. 2014. Phytochemical analysis and a study on the antiestrogenic antifertility effect of leaves of Piper betel in female albino rats. Ancient Sci Life 34 (1): 16

Carolia N, Noventi W. 2016. The potential of green betel leaf (Piper betle L.) for alternative therapy acne vulgaris. J Major 5 (1): 140-145 [Indonesian]

Chauhan ES, Aishwarya J, Singh A, Tiwari A. 2016. A review: Nutraceutical properties of Piper betle (Paan). Am J Phytomed Clin Ther 4 (02): 28-41.

Datta A, Ghoshdastidar S, Singh M. 2011. Antimicrobial property of Piper betle leaf against clinical isolates of bacteria. Intl J Pharma Sci Res 2 (3): 104-109.

Dwivedi V, Tripathi S. 2014. Review study on potential activity of Piper betle. J Pharmacogn Phytochem 3 (4): 93-98.

Fitrianti Y, Ichwansyah F, Wahyudi A, Saifullah, Pratiwi NL. 2015 Gayo's traditional medication for puerperal mother. Heal Syst Bull 18: 111-119.

Hossain F, Anwar M, Akhtar S, Numan S. 2017. Uses impact of betel leaf ( Piper betle L.) on public health. Sci J Publ Health 5 (6): 408-410.

ISE. 2006. International Society of Ethnobiology Code of Ethics (with 2008 additions). www.ethnobiology.net/ethics.php

Kurniawati SLC, Ulfa M. 2015. The differences in the using of betel leaves to the perineum wound recovery. J Nurse Midwifery 2 (3) 227-231.

Lestari H, Suharmiati. 2009. Herbal medicine for sexual life among Madurese women. In: Purwanto, Waluyo EB (eds) Pros Semin Etnomedisin IV. [Indonesian]

Lien LT, Tho NT, Ha DM, Hang PL, Nghia PT, Thang ND. 2015 Influence of phytochemicals in Piper betle Linn leaf extract on wound healing. Burn Trauma 3 (1): 1-8. DOI: 10.1186/ s41038-015-0023-7

Lutviandhitarani G, Harjanti DW, Wahyono F. 2015. Green antibiotic betel leaves (Piper betle) as a substitute for commercial antibiotics in mastitis treatment 15 (1): 28-32.

Marhaeni GA. 2016. Fluor albus among women. J Skala Husada 13 (1): 30-38. [Indonesian]

Mariano LIB, Boquiron Jr RB, Rementilla EP. 2017. Examining the effects of ikmo (Piper betle Linn.) on the thyroxine level of female albino rats and its relationship to infertility and hyperprolactinemia. Int Res J Pharm 8 (7): 137-142.

Mudjijono, Herawati I, Munawaroh SS. 2014. Madura local awareness about jamu for mother's health. First edit. The Cultural Value Conservation Center (BPNB) 81-121. [Indonesian]

Musdja MY, Sadiah U, Putri E. 2019. Activities and mechanisms of Eugenol and essential oil betel leaf (Piper betle Linn) against some bacterial pathogens. Eco Env Cons 25 (3): 1461-1465

Nazmul MHM, Rashid MA JH. 2013. Antifungal activity of Piper betle plants in Malaysia. Drug Discov 6 (17): 16-27.

Nilugal K, Perumal K. 2014. Evaluation of wound healing activity of Piper betle leaves and stem extract in experimental Wistar rats. Am J Pharmtech Res 4 (3): 443-452.
Ningtias AF, Asyiah IN. 2014. Benefits of betel leaf (Piper betle L.) as traditional medicine for internal disease in Kalianget Sub-district Sumenep District, Madura. Universitas Jember, Jember. [Indonesian]

NIHRD. 2000. Indonesian Medicinal Plants Inventory. First Edit. NIHRD Publisher Agency, Jakarta, Indonesia. [Indonesian]

NIHRD. 2012. National Report: Exploration on Local Knowledge of Ethnomedicine and Community-Based Medicinal Plants in Indonesia (RISTOJA 2012). NIHRD Publisher Agency, Jakarta, Indonesia. [Indonesian]

NIHRD. 2015. National Report: Exploration on Local Knowledge of Ethnomedicine and Community-Based Medicinal Plants in Indonesia (RISTOJA 2015). NIHRD Publisher Agency, Jakarta, Indonesia. [Indonesian]

NIHRD. 2017. National Report: Exploration on Local Knowledge of Ethnomedicine and Community-Based Medicinal Plants in Indonesia (RISTOJA 2017). NIHRD Publisher Agency, Jakarta, Indonesia. [Indonesian]

NIHRD. 2013. Indonesia Report: Basic Health Research. 2013. NIHRD Publisher Agency, Jakarta, Indonesia. [Indonesian]

NIHRD. 2018. Main Result of Basic Health Research. Ministry of HealthRepublic of Indonesia RISKESDAS) NIHRD. Publisher Agency, Jakarta, Indonesia. www.depkes.go.id/resources /download /.../hasilriskesdas-2018.pdf [Indonesian]

Patra B, Das MT, Dey SK. 2016. A review on Piper betle L. J Med Plants Stud 4 (6): 185-192.

Pradhan D, Suri K, Pradhan DK, Biswasroy P. 2013. Golden heart of nature: Piper betle L. J Pharmacogn Phytochem 1 (6): 147-167.

Puspa DS, Fatonah A. 2019. The effect of betel quid extract on wound healing process in male Wistar rats ( Rattus norvegicus L.). Asian J Appl Sci 07 (06): 788-797.

Putri RA, Graham-Davies S, Artaria MD. 2018. Traditional body care of women in Madura Island. Masy Kebud dan Polit 31: 339-349. [Indonesian]

Rekha VPB, Kollipara M, Gupta Srinivasa BRSS, Bharath Y, Pulicherla KK. 2014. A Review on Piper betle L.: Nature's promising medicinal reservoir. Am J Ethnomed 1 (5): 276-289.

Sengupta R, Banik JK. 2013. A review on Betel leaf (pan). Int J Pharm Sci Res 4(12): 4519-4524.

Shukla R, Satish V, Singh VK. 2009. Antibacterial activity of fresh leaves of Piper betle Linn. Pharma Res 1: 110-113.

Sucipto TH, Aisyah N, Lestari P, Setyawati H. 2016. Betel leaf essential oil for hemophilia patients and its antibacterial effect on Mycobacterium tuberculosis. Ind J Trop Infect Dis 6 (3): 63-67.

Sulistyowati, Amalia. 2016. The effectiveness differences of the betel leaves and garlic on Flour albus used. Surya 08 (03). [Indonesian]

Shah SK, Garg, Jhade DPN. 2016. Examining the effects of ikmo (Piper betle Linn.) on the thyroxine level of female albino rats and its relationship to infertility and hyperprolactinemia. Intl J Pharm Sci Rev 38 (2): 181-189.

Venkateswarlu K, Devanna N. 2014. Pharmacological evaluations (analgesic activity) of Piper betle. Intl J Pharmamedix India 2 (2): 688-693.

Widyaningtias NMSR, Yustiantara PS, Paramita NLPV. 2014 Antibacterial activity test of purified extract of green betel leaf (Piper betle L.) against Propionibacterium acnes. J Farm Udayana 3 (1): 5053. [Indonesian]

Widyasari R, Diana Sari I, Lailatul A, Haryanto S, Pramono S. 2012. Series of Mother and Child Health Ethnographic Book: Madurese Ethnic, Jrangoan Village, Omben Sub District, Sampang District, East Java Province. Kanisius, Indonesia. [Indonesian]

Zuraidah. 2015. A study on betel leaf extract (Piper sp.) used by women in Bubue Dayah Village, Pidie to cure candidiasis due to Candida albicans fungi. Gend Equal Int J Child Gend Stud 1 (2): 109-118. 